Acta vet. scand. 1964, 5, 146-178.

From the Department of Pathology, State Veterinary Medical Institute, the Department of Anatomy and Histology, the Laboratory for Electron Microscopy, and the Department of Surgery, Royal Veterinary College, Stockholm.

\title{
LIGHT AND ELECTRON MICROSCOPICAL STUDIES OF THE RENAL LESION IN DOGS WITH PYOMETRA
}

By

Anna-Lisa Obel, Lennart Nicander and Åke Åsheim

Renal function studies on bitches with polydipsia in association with pyometra (chronic purulent endometritis) have demonstrated that the renal concentrating ability is invariably reduced and that the glomerular filtration rate is often depressed with a tendency towards a reduction in the filtration fraction (Asheim $1964 \mathrm{a}$ ). The reduction in concentrating ability results from a reduction in the capacity of the distal and collecting tubules for water resorption (Asheim $1964 \mathrm{~b}$ ) and not from dysfunction of the hypothalamic-neurohypophyseal system ( $\AA s$ heim 1963). The lowered resorption capacity in the collecting tubules appears to be associated with a reduction in the sodium gradient in the renal medulla (Asheim $1964 \mathrm{c}$ ).

Few attempts have been made to establish the morphological background to the renal dysfunction in bitches with pyometra. Bloom (1946) reported on the extragenital changes noted in 15 pyometra bitches. Myeloid metaplasia was observed in the liver, spleen, kidneys and adrenals. In his opinion the renal changes represented a concomitant acute or subacute interstitial nephritis which was independent of the uterus lesion. No changes in the renal glomeruli or arteries were recorded. "Large droplet" dege- 
neration with swelling of the epithelial cells, epithelial regeneration with mitosis and, in some instances, an undefined yellow pigment were present in the proximal tubules. Neutrophils had infiltrated the tissue towards the tip of the papilla and in one animal there was focal necrosis at this site as well. Lymphocytes, plasma cells, and a few histocytes had infiltrated the cortex. Two of the bitches had a moderate focal fibrosis with atrophy of the tubuli and glomerular fibrosis. In addition, varying degrees of myeloid metaplasia were encountered in the kidneys of practically all the bitches. The myeloid foci were usually separate from the inflammatory infiltrations. In Bloom's opinion, the renal changes in bitches with pyometra are identical with the common interstitial nephritis of dogs.

Dahme (1956) has described the occurrence of glomerulonephritis in dogs with chronic purulent processes including pyometra. The walls of the glomerular capillaries were thickened, first in the mesangium and later throughout the entire loop. No tubular changes apart from the presence of casts were mentioned.

The present study was undertaken to ascertain whether the renal dysfunction which is characteristic for bitches with pyometra can be associated with histopathological changes. The kidneys from a series of pyometra bitches have been examined by light and electron microscopy.

\section{MATERIAL AND METHODS}

Renal tissue has been examined from 27 pyometra bitches with an anamnesis of increased thirst and from five normal bitches. The diagnosis of pyometra was verified after ovariohysterectomy or at autopsy. Bacteriological examination yielded pure cultures of E. coli from 24 bitches, pure culture of streptococci from one bitch, and sterile cultures from two bitches.

Renal tissue was obtained from three of the bitches after some time had elapsed after ovariohysterectomy. All the bitches were examined by light microscopy and five by electron microscopy as well.

Thirteen of the bitches had been subjected to inulin clearance studies. The degree of reduction of the GFR as established from the clearance studies is illustrated in Fig. 1. The results of the clearance tests and some laboratory examinations for the bitches studied by electron microscopy are given in Table 1. 


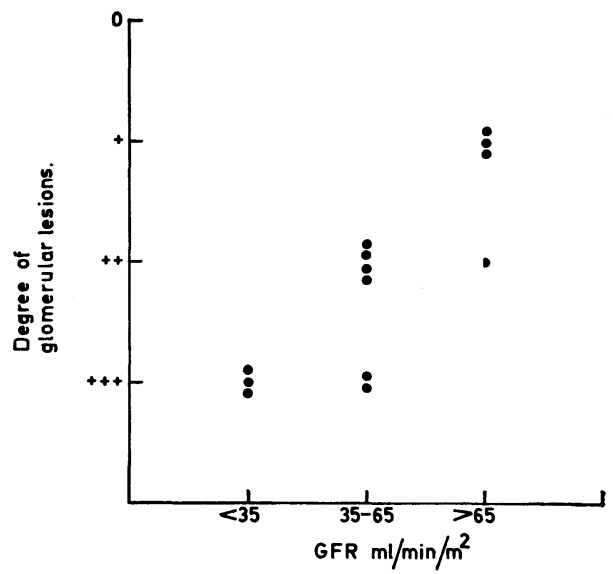

F i g. 1. Glomerular filtration rate related to the degree of glomerular lesions. The lesions are graded + to +++ .

\section{Experimental details}

I. Investigations prior to ovariohysterectomy.

A. Material and sampling technique.

This part of the work covered 27 bitches with pyometra and polydipsia. Samples of renal tissue were obtained from 23 of the bitches in conjunction with therapeutic ovariohysterectomy.

After barbiturate or barbiturate and fluothane anaesthesia and a mid-line incision, the left kidney was freed by blunt dissection so that the hilus could be digitally compressed. A transverse incision was made in the renal capsule and the capsule peeled back cranially and caudally to expose a strip of parenchyma. While the hilus of the kidney was compressed between the thumb and middle finger of the left hand, two parallel and transverse incisions about $1-1.5 \mathrm{~mm}$ apart were made from the surface of the kidney down to the middle of the

T a ble 1. Functional and laboratory values for the five pyometra bitches from which kidney tissue was obtained for electron microscopy.

\begin{tabular}{lccccccccc}
\hline No. & GFR & $\begin{array}{c}\text { Max. } \\
\text { osmotic } \\
\text { U/P } \\
\text { ratio }\end{array}$ & $\begin{array}{c}\text { NPN } \\
\text { mg \% }\end{array}$ & $\begin{array}{c}\text { Total } \\
\text { protein } \\
\mathbf{g} /\end{array}$ & $\begin{array}{c}\text { Albumin- } \\
\text { globulin } \\
\text { ratio }\end{array}$ & $\begin{array}{c}\gamma \text {-glo- } \\
\text { bulin } \\
\text { g/ } \\
100 \mathrm{ml}\end{array}$ & $\begin{array}{c}\text { Chole- } \\
\text { sterol } \\
\text { mg/ } \\
100 \mathrm{ml}\end{array}$ & $\begin{array}{c}\text { Proteinuria } \\
\text { (according } \\
\text { to Heller) } \\
\text { max.: + ++ }\end{array}$ & $\begin{array}{c}\text { Reducing } \\
\text { sub- } \\
\text { stances }\end{array}$ \\
\hline P 96/63 & 25 & 2.1 & 60 & 9.6 & 0.35 & 2.3 & - & $(+)$ & 0 \\
P 235/63 & 57 & 3.1 & 31 & 9.1 & 0.68 & 1.6 & - & $(+)$ & 0 \\
P 236/63 & 63 & 1.2 & 39 & 8.3 & 0.39 & 2.6 & 403 & +++ & 0 \\
O 1314/63 & 74 & 3.0 & 38 & 8.8 & 0.40 & 2.6 & 347 & + & 0 \\
P 470/63 & 16 & 1.7 & 62 & 8.6 & 0.10 & 3.0 & 421 & (lost) & 0 \\
\hline
\end{tabular}


medulla by means of a fine double-edged scalpel. The slice of kidney tissue was then freed at its base with the same scalpel and immediately placed in a fixative. One to two minutes elapsed from compression of the hilus to removal of the biopsy slice. The renal capsule was closed with 000 catgut on atraumatic needles.

B. Light microscopy.

Kidney tissue from all the pyometra bitches in the survey was examined by light microscopy. Five normal bitches ranging from one to six years of age served as controls. Renal tissue from the normal bitches was obtained by the biopsy technique described above.

The biopsy samples were fixed in Bouin's and Carnoy's fluids and in 10 per cent neutral formalin. Frozen sections were made from a portion of the biopsy sample and stained with Scharlach Rot for fat, and the remainder was embedded in paraffin and stained with haematoxylin and eosin, van Gieson's method, PAS, Jones' periodic acid and silver methenamine, Ritter-Oleson's method, methyl-green and pyronine, Weigert's fibrin, the long Ziehl-Neelsen method, v. Kossa's silver stain, azan, Hueck's iron stain, and Lephene's benzidine reaction.

\section{Electron microscopy.}

The five pyometra bitches used for these studies were also included under B. An entire kidney taken immediately after killing was available from the two bitches ( $P$ 96/63 and $O 1314 / 63$ in Table 1) with increased NPN. From the other three bitches with normal NPN renal tissue was obtained by the biopsy technique mentioned above. As control material, a kidney was removed from a three-year-old bitch with normal renal function.

Small pieces from the cortex and outer medulla, and - in two instances - from the tip of the papilla were cut out with a razor blade and fixed for one hour in cold one per cent osmium tetroxide solution (Millonig 1961, Helander 1962). After dehydration, the tissue was embedded in epoxy resin (Epon) (Luft 1961) and sectioned with glass knives on a LKB Ultrotome. Larger and thicker sections (approx. $1 \mu$ ) were stained with buffered toluidine blue solution (Björkman 1962) and examined under a light microscope. Suitable regions were selected, the blocks re-trimmed, and thin sections $(60-100 \mathrm{~m} \mu)$ taken for electron microscopy. The sections were picked up on uncoated copper grids and "stained" with uranyl acetate (Watson 1958) or with lead acetate (Dalton \& Zeigel 1960). A Siemens Elmiskop I at a tension of $80 \mathrm{kV}$ was used; primary magnification ranged from 2,000 to 8,000 times.

II. Investigations after ovariohysterectomy.

Three pyometra bitches with pronounced polydipsia and polyuria were re-examined 14 days, 14 weeks, and five years after ovariohysterectomy. The renal concentrating ability had improved but was not wholly re-established in the bitch examined 14 days after hysterectomy. The other two bitches had regained a normal concentrating ability. A renal biopsy sample had been taken in conjunction with 
ovariohysterectomy of the bitch which was re-examined 14 weeks later by autopsy. The entire kidney was also available from the other two bitches, killed with i.v. Mebumal, 14 days and five years after ovariohysterectomy. The post-operative tissue samples were examined by light microscopy only.

\section{RESULTS}

\section{Macroscopical and light-microscopical observations}

In this account the terms "slight", "moderate", and "severe" will be used in an attempt to denote the relative degree of the morphological changes observed and do not refer to the degree of renal dysfunction.

For most of the kidneys from pyometra bitches, macroscopical changes - if detectable at all - were limited to small depressions of the cortical surface. In some instances, the kidneys were moderately enlarged and the cortex had a light yellow-brown colour (Fig. 21). There were small cortical haemorrhages in a few kidneys.

The slightest degree of changes noted under the light microscope was manifested as thickening of the walls of the glomerular loops, most pronounced towards the centrilobular part of the capillary wall ${ }^{\star}$ ) (Fig. 3 ). The thickened capillary walls were strongly PAS positive (Fig. 22). Under the light microscope it was impossible to determine whether the thickening involved the endothelium, the basement membrane, or the glomerular epithelium. With special stains, Jones' periodic acid and silver methenamine (Fig. 24) and Ritter-Oleson's method (Fig. 23), the basement membrane seemed to account for much of the thickening.

As the degrees of glomerular changes increased from slight to moderate, the thickening of the capillary walls became more pronounced and extended around the entire circumference of the capillary wall (Fig. 4). The thickened capillary walls had a homogeneous, hyaline appearance and were strongly PAS positive. This appearance corresponds to what is termed membranous glome-

*) It has long been debated whether or not an interstitium, a mesangium, exists in the glomerular tuft. "Intercapillary cells" with phagocytic properties (Farquhar \& Palade 1962, Latta \& Maunsbach 1962) are now considered to lie between the endothelium and epithelium and to be partially encircled by processes arising from the basement membrane (Huhn et al. 1962). 
T a b l e 2. Survey of the degree of the kidney lesions in the pyometra bitches.

\begin{tabular}{|c|c|c|c|c|}
\hline No. & $\begin{array}{l}\text { Membranous or } \\
\text { mixed glomerulo- } \\
\text { nephritis }\end{array}$ & $\begin{array}{l}\text { Plasma cell } \\
\text { infiltrations }\end{array}$ & $\begin{array}{l}\text { Hyaline droplets } \\
\text { in prox. } \\
\text { epithelium }\end{array}$ & $\begin{array}{l}\text { Pigment } \\
\text { in prox. } \\
\text { epithelium }\end{array}$ \\
\hline P 2369/62 & + & $\begin{array}{l}0 \text { (small } \\
\text { sample) }\end{array}$ & $(+)$ & $(+)$ \\
\hline P 2822/62 & ++ & ++ & $(+)$ & +++ \\
\hline P 2866/62 & $++(+)$ & ++ & $(+)$ & $(+)$ \\
\hline P 2884/62 & $++(+)$ & ++ & $(+)$ & + \\
\hline P 2885/62 & ++ & ++ & ++ & ++ \\
\hline P $3069 / 62$ & $(+)$ & ++ & +++ & $(+)$ \\
\hline O 3123/62 & $+(+)$ & $(+)$ & + & $(+)$ \\
\hline P 3203/62 & +++ & $++t$ & + (mitosis) & $+(+)$ \\
\hline P $3204 / 62$ & $\begin{array}{c}+(+) \text { (focally } \\
+++)\end{array}$ & $\begin{array}{r}+ \text { (focally } \\
+++\end{array}$ & ++ & ++ \\
\hline P 3205/62 & $+(+)$ & + & $+(+)$ & ++ \\
\hline P $3277 / 62$ & ++ & 0 & ++ & ++ \\
\hline P 3463/62 & +++ & ++ & ++ & ++ \\
\hline P $3483 / 62$ & + & + & $(+)$ & $(+)$ \\
\hline P 3595/62 & ++ & $+t+$ & +++ & +++ \\
\hline P $3670 / 62$ & + & + & ++ & $(+)$ \\
\hline P $4148 / 62$ & $+(+)$ & + & $+(+)$ & +++ \\
\hline P 4149/62 & ++ & + & + & +++ \\
\hline P $4309 / 62$ & ++ & + & +++ & + \\
\hline P $4444 / 62$ & ++ & $(+)$ & + & $++t$ \\
\hline P $4701 / 62$ & + & 0 & $(+)$ & $(+)$ \\
\hline P 4806/62 & $++(+)$ & + & + & ++ \\
\hline O 3105/62 & $+(+)$ & ++ & ++ & $(+)$ \\
\hline P 96/63 & $++(+)$ & +++ & +++ & + \\
\hline P 235/63 & ++ & $(+)$ & ++ & ++ \\
\hline P 236/63 & + & + & ++ & ++ \\
\hline O 1314/63 & +++ & +++ & + & $(+)$ \\
\hline P 470/63 & ++ & + & + & $(+)$ \\
\hline
\end{tabular}

$+\quad=$ slight

$++=$ moderate

$++=$ severe

rulonephritis in human beings. There was a moderate degree of swelling and proliferation of the endothelial cells. The narrowed capillary lumina contained fewer erythrocytes than normal but, on many occasions, numerous neutrophils (Fig. 8). In the intraglomerular portions of the afferent and efferent arterioles the endothelial cells were increased in number and the wall thickened by PAS-positive material. These changes ceased abruptly as the arterioles passed through the capsule. The basement membrane 
of the glomerular capsule often had PAS-positive, focal thickenings. The degree of glomerular changes was seldom uniform; different degrees of damage could be observed in different glomeruli in the same section (Fig. 10).

The most severe degree of glomerular damage resulted in the glomerular capillaries being transformed into coarse PAS-positive tubes. It appeared as though PAS-positive material was deposited under the endothelial cells (Fig. 5). Thickening of the capillary walls reduced the lumina to make the glomeruli ischaemic (Figs. 5 and 7). A few capillaries had aneurysmal dilatations (Fig. 9). Again the degree of changes were not uniform; some capillary loops were much more thickened than others and the lumen could be entirely obliterated. The endothelial cells were swollen, often with proliferation as well (Fig. 9). On the other hand, there were no definite changes in the glomerular epithelium.

In two animals, some glomeruli contained sharply circumscribed, round, hyaline, practically acellular nodules of different sizes (Figs. 13 and 15). The nodules were slightly PAS positive. Their appearance resembled the focal thickening of capillary loops seen in conjunction with diabetes and in chronic lobular glomerulonephritis (Jones 1953, Allen 1962) in human beings. The nodules were generally silver negative but could contain a few silver-positive fibres and cell nuclei (Fig. 14). Focal swelling and proliferation of the endothelial cells in one or several adjacent capillaries seemed to be the first stage in the formation of these nodules. The cytoplasm of the endothelial cells contained coarse PAS-positive granules which sometimes were confluent (Fig. 12). The endothelial cells gradually fused to give the final hyaline mass with its enclosed nuclei.

The basement membrane of the glomerular capsule was thickened, generally focally. The degree of change corresponded to the degree of change in the glomerular capillaries (Figs. 5 and 7). There was also some focal periglomerular fibrosis (Fig. 6), usually with swelling and proliferation of the capsular epithelium. There were a few synechiae between capillary loops and the glomerular capsule (Fig. 5). In many glomeruli the vascular tuft had contracted to leave a large capsule space (Fig. 6). The glomerular changes ultimately resulted in complete obliteration to leave only hyalinized, acellular clumps (Fig. 11).

The glomerular changes were regularly accompanied by changes in the proximal tubules although there was no definite 
parallelism in the degree of changes. The cytoplasm regularly contained hyaline droplets which gave a fairly strong PAS reaction (Fig. 18). These droplets were weakly eosinophilic, stained red with azan, and gave a positive reaction with Weigert's fibrin stain. There were wide variations in the degree of this change. In some kidneys the droplets were sparse, in others they filled the cytoplasm. Proliferation of the proximal epithelium, often with mitoses, was evident in many of the kidneys (Fig. 20). Desquamated cells with pyknotic nuclei could be encountered in the lumina. The lumina of a few nephrons were dilated and contained homogeneous, eosinophilic material.

Another regular change was the presence of a yellow-brown pigment in the cytoplasm of the proximal epithelium. A few pigment granules were also encountered in the distal tubules. The pigment was present as irregularly shaped droplets or flakes in the basal part of the cytoplasm. The larger granules were often oval and situated at right-angles to the base of the cell (Figs. 18 and 25). There was no correlation between the degree of pigment deposition and the degree of glomerular or other tubule changes. No iron could be demonstrated in the pigment granules. Nor could the pigment be bleached by hydrogen peroxide. Some of the smaller pigment granules were PAS positive. The pigment stained deep red after the long Ziehl-Neelsen technique and gave a yellowbrown fluorescence. It did not stain with Sudan black B or other fat stains.

In some of the kidneys with particularly severe glomerulus changes there was an increase in the amount of fat normally present in the straight part of the proximal tubules. No other changes were noted in the loops of Henle. Nor, apart from the slight pigment deposition mentioned above, were there changes in the distal tubules. Protein casts and calcium deposition were encountered in the collecting tubules. In one of the papillary tips which was available for examination calcium deposits appeared as beads on the connective tissue fibres (Fig. 26) and the epithelium of the collecting tubules contained weakly PASpositive cytoplasmic granules. Unlike glycogen which can normally be present at this site, the positive PAS reaction of these granules was not abolished by treatment with diastase.

In kidneys with moderate to severe degrees of glomerular damage a moderate thickening of the basement membrane was evident at all levels of the nephron. The thickening was most 
pronounced in the straight part of the proximal tubules, to some extent possibly because the basement membrane is normally thicker here. In some instances there were also fine knobs on the basement membrane which projected up between the cells (Fig. 19).

In most of the kidneys with a severe degree of damage there was also focal atrophy of tubules in the cortex, probably because of complete obliteration of the corresponding glomeruli. The basement membrane of the atrophic tubules was greatly thickened and strongly PAS positive (Fig. 11). The remnants of the epithelial cytoplasm contained numerous pigment granules. Greatly dilated tubules were also encountered in these regions. Some of the larger regions included numerous completely hyalinized glomeruli.

The cortex of most kidneys was infiltrated fairly heavily with plasma cells of different degrees of maturation together with a few lymphocytes. In some instances neutrophils were also present. Most often, the infiltrating cells were clustered about the glomeruli (Figs. 7 and 9) but they could also be encountered in small groups around tubules. They were always present around atrophic tubules together with haemosiderin-containing macrophages and fibroblasts (Fig. 11).

The incidence and degree of the major changes in the glomeruli and tubules are given in Table 2.

Kidney tissue from one bitch taken by biopsy at ovariohysterectomy could be compared with tissue obtained at autopsy 14 weeks later. Normal renal function had been re-established. In the biopsy specimen, moderate to severe changes were present with hyaline nodules in most of the glomeruli (Fig. 16), numerous hyaline droplets and moderate pigment deposition in the proximal tubules, and diffuse infiltration with plasma cells. In the autopsy specimen, most of the glomeruli were normal and only slight thickening of the capillary walls was evident in a few glomeruli (Fig 17). There were no signs of the hyaline nodules in the glomeruli. The proximal tubules did not contain any hyaline droplets but their pigment content was unchanged. Only a few plasma cells remained in the vicinity of the glomeruli.

A kidney was available from a bitch with normal renal function but which was ovariohysterectomized five years previously because of pyometra associated, according to the anamnesis, with pronounced polydipsia and polyuria. The walls of 
the glomerular capillaries were only slightly thickened, there were no changes in the tubules, and there was no plasma cell infiltration. No biopsy specimen had been taken at the time of ovariohysterectomy for comparison.

There were signs of healing in the kidney tissue obtained from a bitch 14 days after ovariohysterectomy. The walls of the glomerular capillaries were thinner and the numbers of hyaline droplets and infiltrating plasma cells were reduced.

\section{Electron microscopical observations.}

Changes were regularly demonstrated in the glomeruli, some regions of the proximal tubules, the basement membrane of the tubules, the collecting tubules, and the papillary ducts.

The ultrastructure of the glomerulus as observed in the normal bitch agreed with the descriptions of the canine glomerulus by Bergstrand (1957), Movat \& Steiner (1961) and Huhn et al. (1962). The other structures of the canine kidney have not apparently been studied by electron microscopy but our observations on the normal kidney fitted in with the major details described for other animals (Pease $1955 \mathrm{a}, \mathrm{b}, \mathrm{c}$, Rhodin $1958 \mathrm{a}, \mathrm{b}$ and Sakaguchi \& Suzuki 1958).

The glomerular changes involved the endothelium, basement membrane, mesangium and, to a lesser degree, the epithelium. There was slight to moderate swelling of the endothelial cells, mainly resulting from an increase in the perinuclear cytoplasm. Sometimes there were small, dense granules perinuclearly and in the attenuated regions of the cytoplasm (Fig. 28). The basement membrane (lamina densa) was irregularly thickened in all glomeruli examined. The degree of thickening varied greatly from bitch to bitch, from glomerulus to glomerulus in a given kidney section, and even from place to place within a single glomerulus. Normally the basement membrane is about $80 \mathrm{~m} \mu$ thick but in the pyometra bitches the thickness varied between 150 and $1,000 \mathrm{~m} \mu$. Even in slightly affected glomeruli there were numerous places where the basement membrane could be about $400 \mathrm{~m} \mu$ thick. The light cement line along the inner surface of the basement membrane proper (lamina rara interna) was largely obliterated. The corresponding layer on the outer surface was invariably intact. With moderate degrees of thickening the density was much the same as that of the normal basement mem- 
brane (Figs. 28 and 31) but there were generally one or several narrow longitudinal streaks which were somewhat less dense to give the impression of lamination. In four of the kidneys and especially in regions where the basement membrane was particularly thick there were broad and very light regions close to the endothelium or mesangium. They were generally separated from the adjacent cells by a very thin layer of normal density (Fig. 29). In severely affected glomeruli there were also deposits in these "moth-eaten" regions of the membrane or along its inside surface (Figs. 30 and 31). The deposits were irregularly distributed throughout the glomerulus and consisted of a homogeneous material with an electron density exceeding that of the basement membrane. Bowman's capsule was distinctly thickened and sometimes laminated but did not apparently have any deposits. The mesangium was swollen to some extent with relatively large, polymorphous and often very dense cytoplasmic inclusions, particularly in the two bitches with deposits within or along the inner surface of the basement membrane (Fig. 31). There were generally only slight changes in the epithelium. Some degree of swelling was common as were a few large vacuoles and moderately electron-dense droplets in the cytoplasm. Focal fusion of the foot processes was seen in all the bitches (Figs. 28 and 30). This change was very pronounced in the bitch ( $P$ 236/63, Table 2) with heavy proteinuria prior to ovariohysterectomy.

In the intermediate portions of the proximal tubules there were numerous large cytoplasmic vesicles containing material of different densities and structure (Fig. 32). The mitochondria appeared to be normal without any tendency to collect around the vesicles or be incorporated in them. A few large, angular cytoplasmic inclusions with great electron density and indistinct internal structure were also encountered (Fig. 33). These doubtlessly correspond to the pigment granules seen by light microscopy.

There were no noteworthy epithelial changes at other levels of the nephron. However, the basement membrane of all renal tubules was greatly thickened. Adjacent intertubular tissue seemed to contribute material for this thickening since there was often accumulation of a cloudy extracellular material close to the blurred outer contour of the basement membrane. Fine, dense, irregular particles were also enclosed in the outer portion of the basement membrane (Fig. 34). In one kidney there were a few 
deposits of 'dense material between the epithelium and the basement membrane. Similar changes were never observed in the basement membranes of the blood vessels.

The interstitium often contained groups of immature plasma cells, sometimes with a few neutrophils. Macrophages with inclusions of different sizes, density, and shape were also encountered, particularly at the periphery of the cell groups.

The cytoplasm in the papillary ducts of one kidney ( $P$ 96/63, Table 2) contained numerous, round, very dense inclusions. Similar but fewer cytoplasmic inclusions were observed in adjacent collecting tubules. They were very sparse in the outer medulla and the cortex. In the other bitch examined ( $O$ 1314/63) there were a few similar cytoplasmic granules in the epithelium of the papillary ducts but practically none in the collecting tubules. No inclusions of this type were observed in the other three kidneys but only the outer medulla was available for examination.

\section{DISCUSSION}

The glomerular changes observed under the light microscope in kidneys from bitches with pyometra correspond to the changes of membranous or mixed membranous and proliferative glomerulonephritis in human beings (Fiaschi et al. 1959). From the electron microscopical observations, however, it appears that there are no deposits on the outer surface of the basement membrane under the epithelial cells (extrinsic membranous deposits) and generally no widespread fusion of the foot processes of the epithelial cells. The major changes involved the basement membrane and the endothelial and mesangial cells.

The electron microscopical appearance resembles that described by Movat et al. (1961) for experimental nephrotoxic nephritis in dogs. The numerous inclusions in the mesangial cells of severely affected glomeruli probably result from these cells strongly engaging in phagocytosis of the increased amount of "filtration residues" resulting from the endothelial injury (Farquhar \& Palade 1962). The generally slight degree of fusion of the foot processes accords with the relatively slight proteinuria.

The glomerular capillaries often contained numerous neutrophils. This is a common observation in acute nephritis and is ascribed to "stickiness" of the capillary walls and adhesion of neutrophils (Jones 1953, 1957). 
The hyaline nodules in some glomeruli correspond morphologically to the Kimmelstiel-Wilson nodules in human beings with diabetes. Allen (1962) has demonstrated that these nodules arise through abrupt hyalinization of one or several capillary walls with stenosis or occlusion of the lumen. Deposition of hyaline takes place in the cytoplasm of the endothelial cells according to Bergstrand \& Bucht (1957). Latta et al. (1960), on the other hand, considers the mesangial cells to be the probable site. A similar pathogenesis is likely for the glomerular nodules in the pyometra bitches but it could not be determined whether the hyaline deposits lie in the endothelial cells or the mesangial cells since no nodules happened to be present in the kidney samples examined by electron microscopy.

GFR has been determined for 13 of the pyometra bitches in this series and compared with the degree of glomerular damage evaluated - subjectively - as slight $(+)$, moderate $(++)$, or severe $(+++)$. There appears to be a good correlation between the degree of glomerular changes and reduction of the GFR.

The renal injury in pyometra bitches is associated with a tendency $(0.05>\mathrm{P}>0.01)$ towards a reduction in the filtration fraction (Åsheim $1964 \mathrm{a}$ ). A reduction in the filtration fraction is characteristic for acute glomerulonephritis in human beings (Parrish et al. 1961).

The changes observed in the proximal tubules - hyaline cytoplasmic droplets, degenerative nuclear changes, mitosis are also common in the various types of nephritis in human beings. The hyaline PAS-positive droplets are now believed to consist mainly of protein from the tubules resorbed by pinocytosis and surrounded by PAS-positive material from the cell membrane (see Forster 1961). The electron micrographs show a greatly increased content of protein absorption droplets (Brewer \& Eguren 1962) but no definite changes in other structures. The proliferative changes seen in many of the kidneys can be considered as a reaction to the increased activity of the tubules.

The yellow-brown pigment in the tubular epithelium of all the pyometra bitches gave, except for the absence of stainable lipid, the staining reactions of lipofuscin. Deposition of this pigment has not been observed in glomerulonephritis in human beings. According to Siebert et al. (1962), lipofuscin consists of lipid, protein and a melanin-containing component. It is conceivable that the metabolism of the cells engaged in protein 
resorption becomes blocked and incapable of breaking down and passing protein and lipid through the cells and that this results in the formation of the pigmented material.

In some kidneys the focal tubule atrophy was quite extensive. Wachstein \& Lange (1959) have followed the pathogenesis of the same change in rats with nephrotoxic nephritis and with nephrosis caused by puromycin and aminonucleoside. According to them, the tubular atrophy is caused by precipitated protein casts or hyaline droplets in the epithelium or both these in conjunction. In the pyometra bitches, protein casts were relatively sparse and hyaline droplets seldom so numerous that they could be considered responsible. On the other hand, hyalinized nonfunctioning glomeruli were regularly present close to the atrophic foci. It appears most likely, then, that gradual obliteration of scattered glomeruli, particularly in the more severely affected kidneys, is the cause of the focal tubular atrophy.

The fine structure of the cytoplasmic granules in the papillary ducts resemble those resulting from protein resorption although pinocytosis could not be seen with the electron microscope.

The basement membrane of the tubules was usually thickened in the pyometra bitches. This change has often been described in conjunction with glomerulonephritis in human beings and has generally been interpreted as a non-specific reaction (Berger $\&$ Galle 1962). It is also seen in diabetic nephrosclerosis (Farquhar et al. 1959).

The only change observed in the renal medulla which could be connected with the reduction in sodium gradient and resorption capacity for free water in the collecting tubules was the thickening of tubular basement membrane.

The pathogenesis of the various types of glomerulus injury encountered in human beings is incompletely known. Acute and chronic proliferative glomerulonephritis can often be associated with streptococcal infections and it generally heals without recurrence if the primary infection is adequately treated. Membranous glomerulonephritis, the most common cause of the nephrotic syndrome and included in Ellis' type II glomerulonephritis, is generally not accompanied by a primary disease and there is little tendency towards healing.

Heterologous renal tissue can induce the formation of circulating antibodies in experimental animals. If these antibodies are injected into an animal of the species from which the renal 
tissue was obtained, they induce renal damage resembling acute glomerulonephritis when given in small doses and membranous glomerulonephritis when given in large doses (Masugi 1933, Smadel 1937, Erich et al. 1952). This type of renal injury is referred to as nephrotoxic nephritis. The strongest antigenic effect in kidney tissue is exerted by the glomerular basement membrane (Krakower \& Greenspon 1954; Steblay \& Lepper 1961).

As an explanation of the pathogenesis of acute glomerulonephritis in human beings it has been proposed that either streptococcus antigen combines with a component of the basement membrane to form an antigen complex which induces the formation of antibodies (Jones 1957) or that the antibodyforming cells of the body are altered as a result of infection and form antibodies against the normal kidney antigen (de Wardener 1961). These antibodies then induce a type of Arthus' reaction in the glomerulus.

Dixon et al. (1961), however, have demonstrated that injection of a foreign protein (bovine serum albumin) without the use of anti-kidney antibodies can induce glomerulonephritis. They believe that the immunobiological phase in the process takes place outside the kidneys to form a circulating antigenantibody complex. The composition and the kidney-damaging propensity varies with the relation between the amount of antigen administered and the amount of antibody formed. Localisation of the antigen-antibody complex in the glomerulus is governed by physical and chemical factors and not by an immunobiological process.

There are some considerations which suggest that the renal injury in pyometra bitches is mediated by an immunological process.

1. The morphological similarity with nephrotoxic nephritis in dogs and acute proliferative glomerulonephritis in human beings.

2. The presence of plasma cells in the renal cortex, particularly around the glomeruli.

3. The development of the renal changes in association with an infection and their healing after removal of the focus of infection.

4. The latent period between the probable time (oestrus) of infection of the uterus and the renal damage. 
It is likely that the antigen involved in the kidney-damaging antigen-antibody complex originates from the uterus, either as a bacterial antigen or from damaged uterine tissue. Streptococcal antigens are the only ones recognized to be effective in inducing glomerulonephritis in human beings. E. coli, the organism most commonly isolated from pyometra bitches, has not hitherto been associated with renal damage. In this context it can be mentioned that Boss (1963) for human beings and Seegal et al. (1955) for dogs and rats have demonstrated that placenta and kidney contain identical or at least very closely related antigens and that anti-placenta serum can induce glomerulonephritis in dogs and rats. Boss (1963) suggested that the renal lesions of human pregnancy toxaemia (Spargo et al. 1959, Farquhar 1959, Pollack \& Nettles 1960) - lesions resembling those of pyometra nephritis - could result from a reaction between antiplacenta antibodies and glomerular antigen. Similarly, it is possible that pyometra nephritis is an immunobiological phenomenon resulting from such a reaction. The methods used in the experimental studies cited above do not exclude the possibility that the placenta antigen used also represented the maternal placenta. With this in mind, it is conceivable that fragments of uterine tissue in bitches with pyometra, possibly in conjunction with bacterial products, contribute to the formation of anti-uterus antibodies which can then cross-react with glomerular antigen.

\section{LITERATURE}

Allen, A. C.: The Kidney. Second ed. 1962. Grune \& Stratton. New York. Åsheim, A.: Renal function in dogs with pyometra. 1. Studies of the hypothalamic-neurohypophyseal system. Acta vet. scand. 1963, 4, 281-291.

Åsheim, A.: Renal function in dogs with pyometra. 3. Glomerular filtration rate, effective renal plasma flow and the relation between solute excretion rate and concentrating ability during dehydration. Acta vet. scand. 1964 a, 5, 56-73.

Åsheim, Å.: Renal function in dogs with pyometra. 4. Maximum concentrating capacity during osmotic diuresis. Acta vet. scand. 1964 b, 5, 74-87.

Åsheim, A.: Renal function in dogs with pyometra. 5. Sodium content of kidneys with reduced concentrating ability. Acta vet. scand. 1964 c, 5, 88-98.

Berger, J. \& Galle, P.: Altération singulière des membranes basales du rein. J. d'Urol. et de Néphrol. 1962, 68, 116-127. 
Bergstrand, A.: Electron microscopic investigations of the renal glomeruli. Lab. Invest. 1957, 6, 191-204.

Bergstrand, A. \& Bucht, H.: Electronmicroscopic investigations on the glomerular lesions in diabetes mellitus (diabetic glomerulosclerosis). Lab. Invest. 1957, 6, 293-300.

Björkman, N.: Low magnification electron microscopy in histological work. Acta morph. neerl.-scabd. 1962, 4, 344-348.

Bloom, F.: The extragenital lesions of canine pyometra. Cornell Vet. $1946,36,324-342$.

Boss, J. H.: The antigen distribution pattern of the human placenta. An immunofluorescent microscopic study using the kidney as an experimental model. Amer. J. Path. 1963, 12, 332-342.

Brewer, D. B. \& Eguren, L. M.: The fine structure of protein droplets in the proximal convoluted tubule of the mouse kidney. J. Path. Bact. 1962, 83, 107-116.

Dalton, A. J. \& Zeigel, R. F.: A simplified method of staining thin sections of biological material with lead hydroxide for electron microscopy. J. biophysic. and biochem. Cytol. 1960, 7, 409-410.

Dahme, E.: Die Morphologie der Nephrosen des Hundes unter Berücksichtigung der Klinik. Dtsch. tierärztl. Wschr. 1956, 63, 49-53.

Dixon, F., Feldman, J. \& Vazquez, J.: Experimental glomerulonephritis. The pathogenesis of a laboratory model resembling the spectrum of human glomerulonephritis. J. exp. Med. 1961, 113, 899-920.

Erich, E. W., Forman, C. W. \& Seifer, J.: Diffuse glomerulonephritis and lipoid nephrosis; correlation of clinical, morphological and experimental observations. Arch. Path. 1952, 54, 463-503.

Farquhar, M. G.: Review of normal and pathologic glomerular ultrastructure. Proc. 10th Ann. Conf. on Nephrotic Syndrome. New York, 1959.

Farquhar, M. G., Hopper, J. \& Moon, H. D.: Diabetic glomerulosclerosis: electron and light microscopic studies. Amer. J. Path. 1959, $35,721-753$.

Farquhar, M. G. \& Palade, G. E.: Functional evidence for the existence of a third cell type in the renal glomerulus. Phagocytosis of filtration residues by a distinctive "third" cell. J. Cell Biol. $1962,13,55-87$.

Fiaschi, E., Andres, G., Giacomelli, F. \& Naccarato, R.: Renal histopathology in the para-nephritic nephrotic syndrom. Scientia med. ital. 1959, $7,639-742$.

Forster, R. P.: Kidney cells. The Cell ed. by J. Brachet \& A. E. Mirsky, New York \& London, 1961, 5, 89-162.

Helander, $H$. F.: Ultrastructure of fundus glands of the mouse gastric mucosa. J. Ultrastruct. Res. 1962, Suppl. 4, 1-123.

Huhn, D., Steiner, J. W. \& Movat, H. Z.: Die Feinstruktur des Mesangiums im Nierenglomerulum von Hund und Maus. Z. Zellforsch. $1962,56,213-230$.

Jones, D. B.: Glomerulonephritis. Amer. J. Path. 1953, 29, 33-52. 
Jones, D. B.: The Kidney. Inflammatory and vascular diseases of the glomerulus. Analytical Pathology. New York, 1957, 160-217. Ed. R. Mellors.

Krakower, C. A. \& Greenspon, S. A.: Factors leading to variation in concentration of "nephrotoxic" antigen (s) of glomerular basement membrane. Arch. Path. 1954, 58, 401-432.

Latta, H., Maunsbach, A. \& Madden, S.: The centrolobular region of the renal glomerulus studied by electron microscopy. J. Ultrastruct. Res. 1960, 4, 455-472.

Latta, H. \& Maunsbach, A.: Relations of the centrolobular region of the glomerulus to the juxtaglomerular apparatus. J. Ultrastruct. Res. $1962,6,562-578$.

Luft, J. H.: Improvements in epoxy resin embedding methods. J. biophys. biochem. Cytol. 1961, 9, 409—417.

Masugi, M.: UUber das Wesen der spezifischen Veränderungen der Niere und der Leber durch das Nephrotoxin bzw. das Hepatotoxin. Zugleich ein Beitrag zur Pathologenese der Glomerulonephritis und der eklamptischen Leberkrankung. Beitr. pathol. Anat. 1933, 91, 82-112.

Millonig, G.: Advantages of a phosphate buffer for $\mathrm{OsO}_{4}$ solutions in fixation. J. appl. Phys. 1961, 32, 1637.

Movat, H.Z. \& Steiner, J. W.: Studies of nephrotoxic nephritis. I. The fine structure of the glomerulus of the dog. Amer. J. clin. Path. $1961,36,289-305$.

Movat, H. Z., Mc Gregor, D. \& Steiner, J. W.: Studies of nephrotoxic nephritis. II. The fine structure of the glomerulus in acute nephrotoxic nephritis of dogs. Amer. J. clin. Path. 1961, 36, 306 -321 .

Parrish, A. E., Kramer, N. C., Hatch, F. E., Watt, M. F. \& Howe, J. S.: The relation between glomerular function and histology in acute glomerulonephritis. J. lab. \& clin. Med. 1961, 58, 197-203.

Pease, D. C.: Electron microscopy of the vascular bed of the kidney cortex. Anat. Rec. 1955a, 121, 701-722.

Pease, D. C.: Electron microscopy of the tubular cells of the kidney cortex. Anat. Rec. 1955 b, 121, 723-744.

Pease, D. C.: Fine structure of the kidney as seen by electron microscopy. J. Histochem. Cytochem. 1955 c, 3, 295-308.

Pollak, V. E. \& Nettles, J. B.: The kidney in toxemia of pregnancy; a clinical and pathologic study based on renal biopsies. Medicine $1960,39,469-526$.

Rhodin, J.: Anatomy of kidney tubules. Int. Rev. Cytol. 1958 a, 7, 485534.

Rhodin, J.: Electron microscopy of the kidney. Amer. J. Med. 1958 b, $24,661-675$.

Sakaguchi, H. \& Suzuki, Y.: Fine structure of renal tubule cells. Keijo J. Med. 1958, 7, 17-38. 
Seegal, B. C., Hasson, M. W., Gaynor, E. C. \& Rothenberg, M. S.: Glomerulonephritis produced in dogs by specific antisera. I. The course of the disease resulting from injection of rabbit antidogplacenta serum or rabbit antidog-kidney serum. J. exp. Med. 1955, 102, 789-805.

Siebert, G., Diezel, P. B., Jahr, K., Krug, E., Schmitt, A., Grünberger, E. \& Bottke, I.: Isolierung und Eigenschaften von Lipofuscin aus Herzgewebe des Menschen. Histochemie 1962, 3, 17-45.

Smadel, J.: Experimental nephritis in rats induced by injection of anti-kidney serum. III. Pathological studies of the acute and chronic disease. J. exp. Med. 1937, 65, 541-555.

Spargo, B., Mc Cartney, C. \& Winemiller, R.: Glomerular capillary endotheliosis in toxemia of pregnancy. Arch. Path. 1959, 68, $593-599$.

Steblay, R. \& Lepper, M.: Some immunological properties of human and dog glomerular basement membranes. J. Immunol. 1961, 87, $636-646$.

Wachstein, M. \& Lange, K.: Proteinuria and tubular atrophy in the rat. Am. J. clin. Path. 1959, 32, 371-383.

de Wardener, H.: The Kidney. London, 1961.

Watson, M. L.: Staining of tissue sections for electron microscopy with heavy metals. J. biophys. biochem. Cytol. 1958, 4, 475-478.

\section{SUMMARY}

Kidney biopsies from 23 bitches with pyometra and an entire kidney from four pyometra bitches were examined by light microscopy. Kidney tissue was also taken from three bitches at different intervals after ovariohysterectomy for pyometra. All the pyometra bitches had membranous glomerulonephritis or mixed proliferative and membranous glomerulonephritis. Two of the bitches had intraglomerular hyaline nodules resembling those seen in conjunction with diabetes in human beings. The degree of glomerular damage could be correlated with the reduction in glomerular filtration rate determined by function tests. The proximal tubules generally contained numerous hyaline droplets but the degree of this change could not be correlated to the degree of glomerular damage. A yellow pigment, a lipofuscin, was regularly present in the proximal tubules as well as epithelial proliferation and mitoses. Focal atrophy of tubules also occurred, presumably because of obliteration of glomeruli. The cortical interstitium contained collections of mature and immature plasma cells, often surrounding the glomeruli.

When the kidneys from three bitches were examined after ovariohysterectomy for pyometra, the glomerular damage in two had regressed to leave only slight thickening of the capillary walls. In the third bitch, examined only 14 days after ovariohysterectomy, healing was partial.

Kidney tissue from five bitches was also examined by electron microscopy. The glomerular endothelial cells were swollen and the 
basement membrane was grealy thickened. With more severe degrees of glomerular damage, an electron-dense material was deposited along the inner surface of the basement membrane and the swollen mesangial cells contained numerous inclusions. There was focal fusion of the foot processes of the glomerular epithelial cells; in one bitch with heavy proteinuria, the fusion was widespread. The proximal tubules contained numerous protein absorption droplets representing resorbed protein. The tubular basement membrane at all levels was thickened.

Because of similarities with some other types of renal damage (nephrotoxic nephritis in dogs and acute proliferative glomerulonephritis in human beings), the possibility is broached that the renal lesion in pyometra is the result of an immunobiological process.

\section{ZUSAMMENFASSUNG}

Licht- und elektronenmikroskopische Untersuchungen der Nieren bei Hunden mit Pyometra.

Lichtmikroskopische Untersuchungen wurden an 23 Nierenbiopsien und 4 Nieren von Hunden mit Pyometra durchgeführt. Nieren von 3 Hunden mit Pyometra, die kürzere oder längere Zeit nach Hysterektomie getötet wurden, wurden untersucht. Bei den Pyometrafällen wurde in den Glomeruli eine membranöse oder membranösproliferative Glomerulonephritis beobachtet.

In zwei Fällen fand man in den Glomeruli hyaline Knoten, die den hyalinen Knoten ähnlich waren, die bei Diabetes der Menschen vorkommen können. Die Glomerulischädigung stand in Korrelation mit der bei Funktionsuntersuchung festgestellten Verminderung der Filtrationsgeschwindigkeit.

In den proximalen Tubuli wurden mehr oder weniger zahlreiche hyaline Tropfen nachgewiesen; der Grad dieser Veränderung stand jedoch nicht im Zusammenhang mit der Glomerulischädigung. Es wurde regelmässig in proximalen Tubuli ein gelbes Pigment nachgewiesen, das für Lipofuscin gehalten wird, als auch eine gesteigerte Zellproliferation und das Vorkommen von Mitosen. Im Interstitium der Nierenrinde fand man ein Infiltrat, das überwiegend aus reifen und unreifen Plasmazellen bestand. Die Infiltrate befanden sich oft in der Nähe von Glomeruli.

Bei Nierenuntersuchungen nach der Hysterektomie, die wegen einer Pyometra durchgeführt wurde, fand man in zwei Fällen eine Ausheilung der Nierenschädigung, wobei nur eine leichte Anschwellung der Kapillarwände in den Glomeruli zurückblieb.

Bei elektronenmikroskopischer Untersuchung von 5 Fällen fand man in den Glomeruli eine Hypertrophie der Endothelzellen und eine starke Anschwellung der Basalmembran. In den schwersten Fällen fand man auch eine Überschichtung mit elektronendichter Substanz an der Innenseite der Basalmembran und zahlreiche Inklusionen in den mesangialen Zellen. Diese waren im allgemeinen hypertrophisch. Die Epithelzellen zeigten fokale Fusionen von Fussprozessen und in einem Falle (mit hochgradiger Proteinurie), fand man ausgedehnte 
Fusionen. In den proximalen Tubuli wurden zahlreiche Proteinabsorptionstropfen gefunden. In allen Tubuliabschnitten wurde eine Verdickung der Basalmembran gefunden.

Auf Grund der Ähnlichkeit mit gewissen anderen Nierenschädigungen (nephrotoxische Nephritis des Hundes und akute proliferative Glomerulonephritis des Menschen) wird hypothetisch gehalten, dass die Nierenschädigung bei Pyometra durch einen immunologischen Prozess verursacht ist.

\section{SAMMANFATTNING}

Ljus- och elektronmikroskopiska undersökningar av njurskadan vid pyometra hos hund.

Ljusmikroskopiska undersökningar av 23 njurbiopsier och 4 hela njurar från hundar med pyometra ha utförts. I 3 fall ha njurar undersökts från hundar, som avlivats kortare eller längre tid efter hysterektomi på grund av pyometra. I glomeruli iakttogs i pyometrafallen en membranös eller blandad membranös och proliferativ glomerulonefrit. I två fall sågs hyalina knutor i glomeruli, vilka liknade de hyalina knutor, som kunna förekomma vid diabetes hos människa. Glomeruliskadan var korrelerad till den vid funktionsundersökningen iakttagna minskningen i filtrationshastigheten.

I proximala tubuli påvisades mer eller mindre rikligt med hyalina droppar, men graden av denna förändring var icke korrelerad till glomeruliskadan. I proximala tubuli påvisades regelbundet ett gult pigment, som ansågs vara lipofuscin, samt ökad cellproliferation och förekomst av mitoser. Härdformigt sågs atrofi av tubuli orsakad av undergång av glomeruli. I interstitiet $i$ barken funnos infiltrat övervägande bestående av mogna och omogna plasmaceller. Infiltraten lågo ofta intill glomeruli.

Vid undersökning av njurarna efter hysterektomi på grund av pyometra iakttogs i två fall en avläkning av njurskadan så att endast en lindrig ansvällning av kapillärväggarna $i$ glomeruli återstod.

Vid elektronmikroskopisk undersökning av 5 fall iakttogs i glomeruli en hypertrofi av endotelcellerna samt en stark ansvällning av basalmembranen. I de gravaste fallen funnos även pålagringar av en elektrontät substans på basalmembranens insida och talrika inklusioner i de mesangiala cellerna. Dessa voro i allmänhet hypertrofiska. Epitelcellerna visade huvudsakligen fokala fusioner av fotprocesserna och i ett fall (med höggradig proteinuri) funnos utbredda fusioner. I proximala tubuli sågos rikligt med proteinabsorptionsdroppar. I alla tubuliavsnitt sågs förtjockning av basalmembranen.

På grund av likheten med vissa andra njurskador (nefrotoxisk nefrit hos hund och akut proliferativ glomerulonefrit hos människa) framkastas hypotesen att njurskadan vid pyometra orsakas av en immunopatologisk process. 

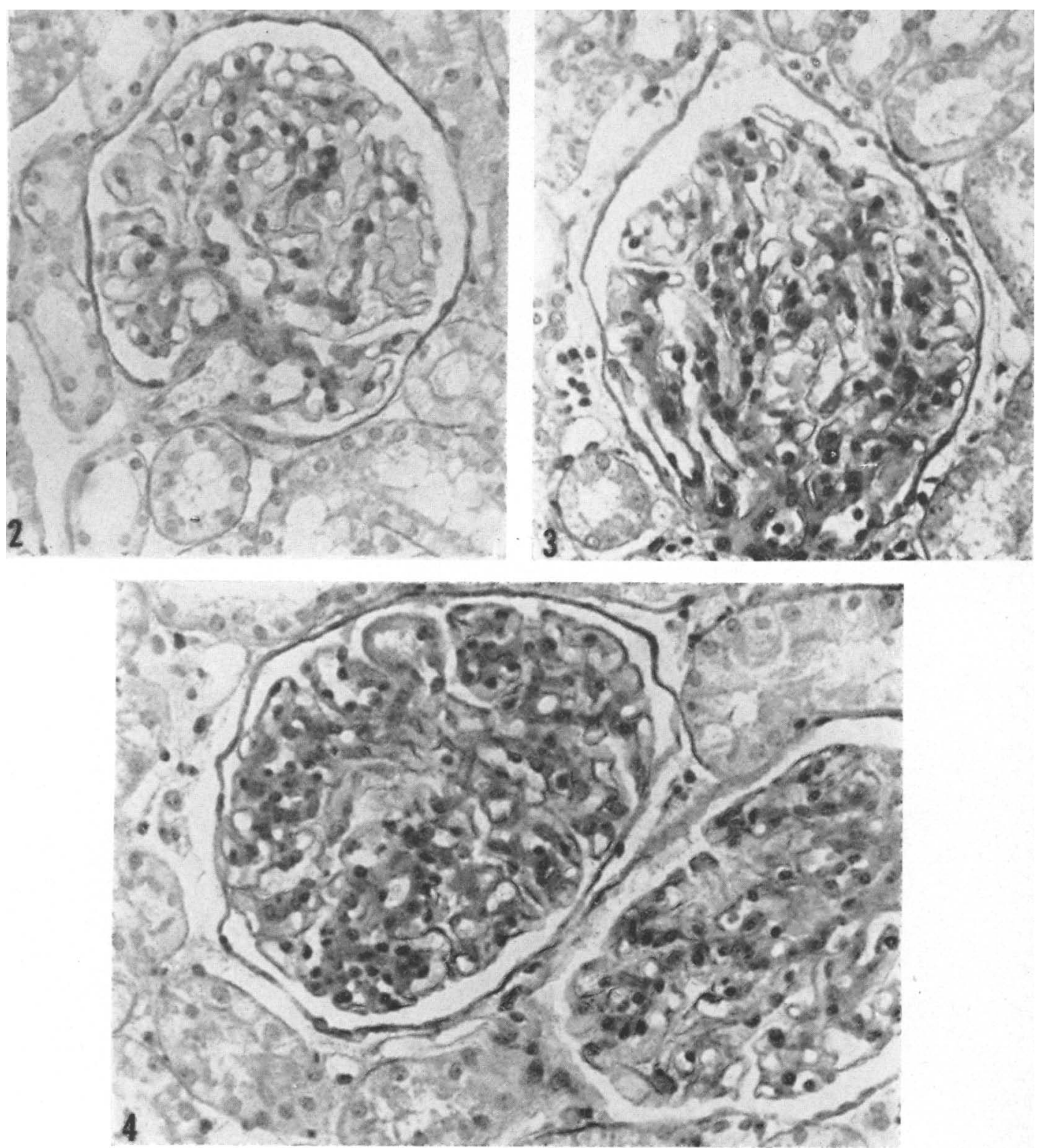

F i g. 2. Normal canine kidney. PAS, $300 \times$.

F i g. 3. P 4148/62. Moderate membranous glomerulonephritis. Thickening of the capillary walls, particularly centrilobularly. PAS, $300 \times$.

Fig. 4. P 2884/62. Moderate membranous glomerulonephritis. More diffuse thickening of the capillary walls. Moderate endothelial proliferation. PAS, $300 \times$. 

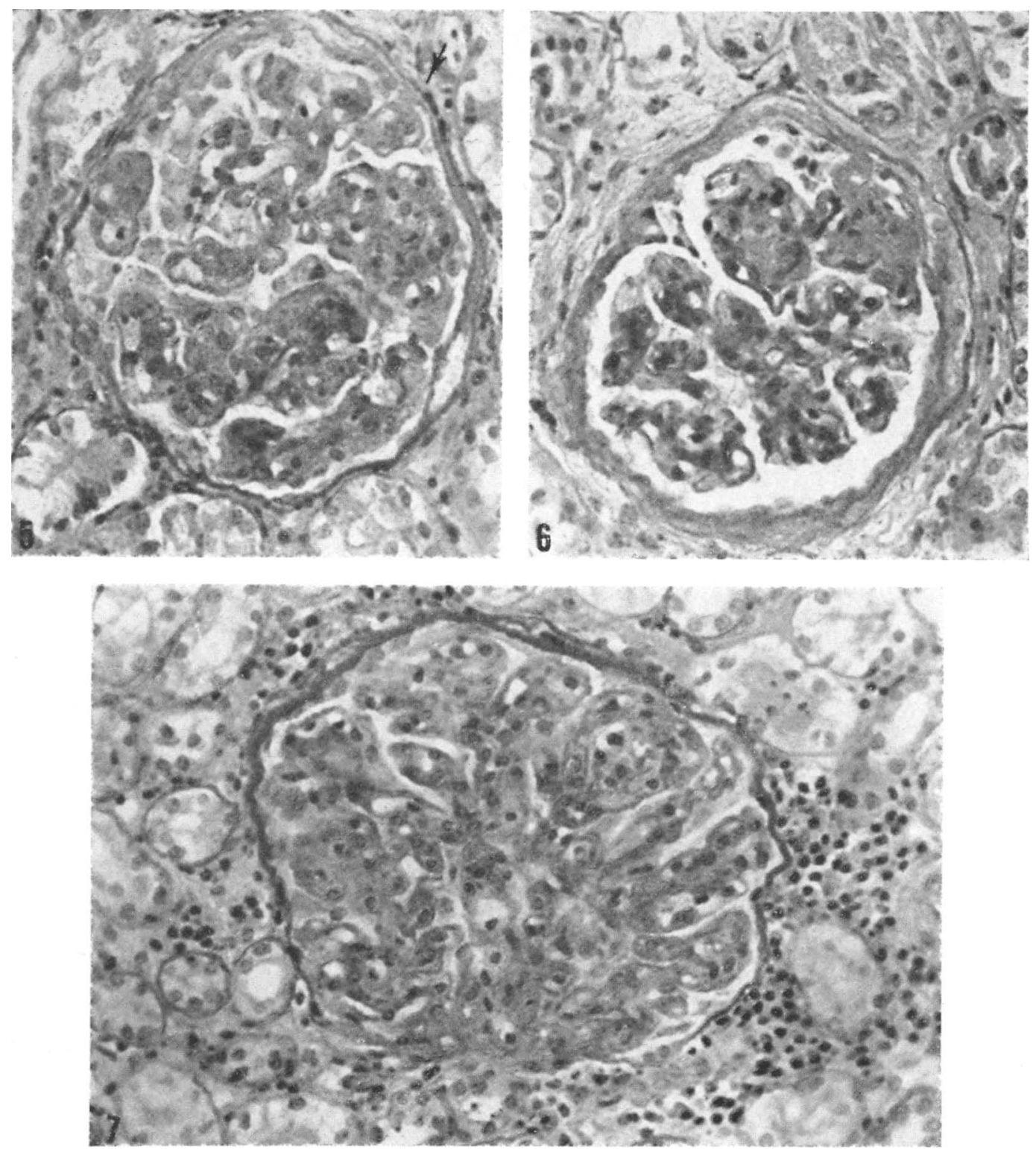

F i g. 5. P 3463/62. Severe membranous glomerulonephritis. The capillary walls are greatly thickened and strongly PAS positive. The lumen of many capillary loops is obliterated. Moderate endothelial proliferation. There are a few synechiae between the tuft and Bowman's capsule (arrow). Great thickening of the basement membrane in Bowman's capsule. PAS, $300 \times$.

F i g. 6. Same kidney as in Fig. 5. This glomerulus is non-functional and is becoming obliterated. The capillary loops lack a lumen. Fibrous induration of Bowman's capsule. PAS, $300 \times$.

Fig. 7. $P$ 96/63. Severe mixed membranous and proliferative glomerulonephritis. The capillary walls are greatly thickened and most capillaries lack a lumen. Pronounced swelling and proliferation of the endothelial cells. Moderate, irregular thickening of the basement membrane in Bowman's capsule. Plasma cell infiltration in the cortical interstitium. PAS, $300 \times$. 

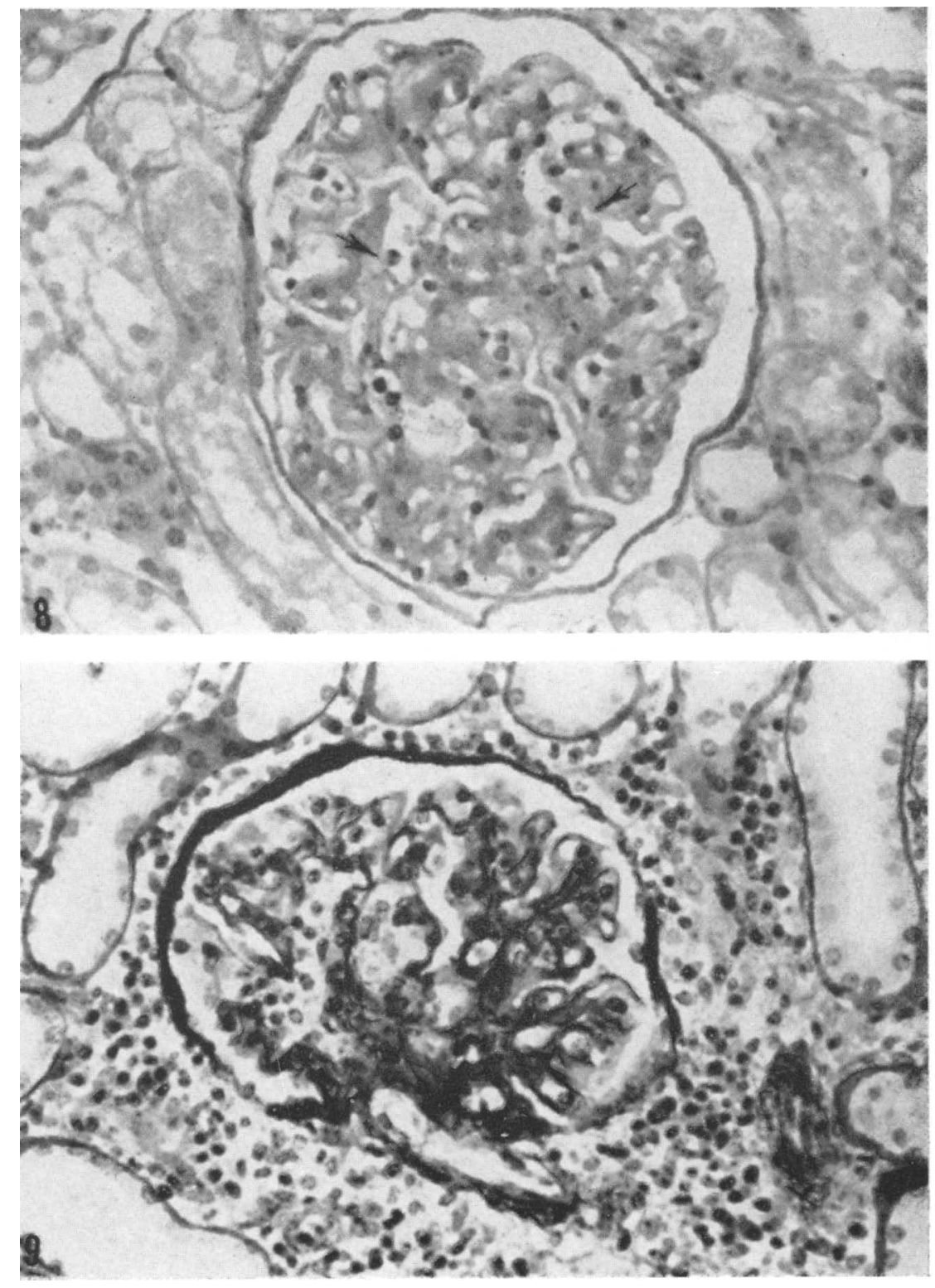

F i g. 8. P 2822/62. Moderate mixed membranous and proliferative glomerulonephritis. The centrilobular portions of the capillary walls are thickened and PAS positive. Moderate proliferation and swelling of the endothelium. Numerous neutrophils in the capillaries (arrows). PAS, $300 \times$.

F i g. 9. O 1314/63. Severe mixed membranous and proliferative glomerulonephritis. Moderate thickening of the capillary basement membrane. The basement membrane appears to be split in several places. Severe swelling and proliferation of the endothelial cells. Most of the capillaries in the right half of the glomerulus have a reduced lumen. Two capillaries in the left half have aneurysmal dilatations. Moderate, irregular thickening of the basement membrane in Bowman's capsule. Heavy periglomerular plasma cell infiltration. Jones' periodic acid and silver methenamine, $300 \times$. 

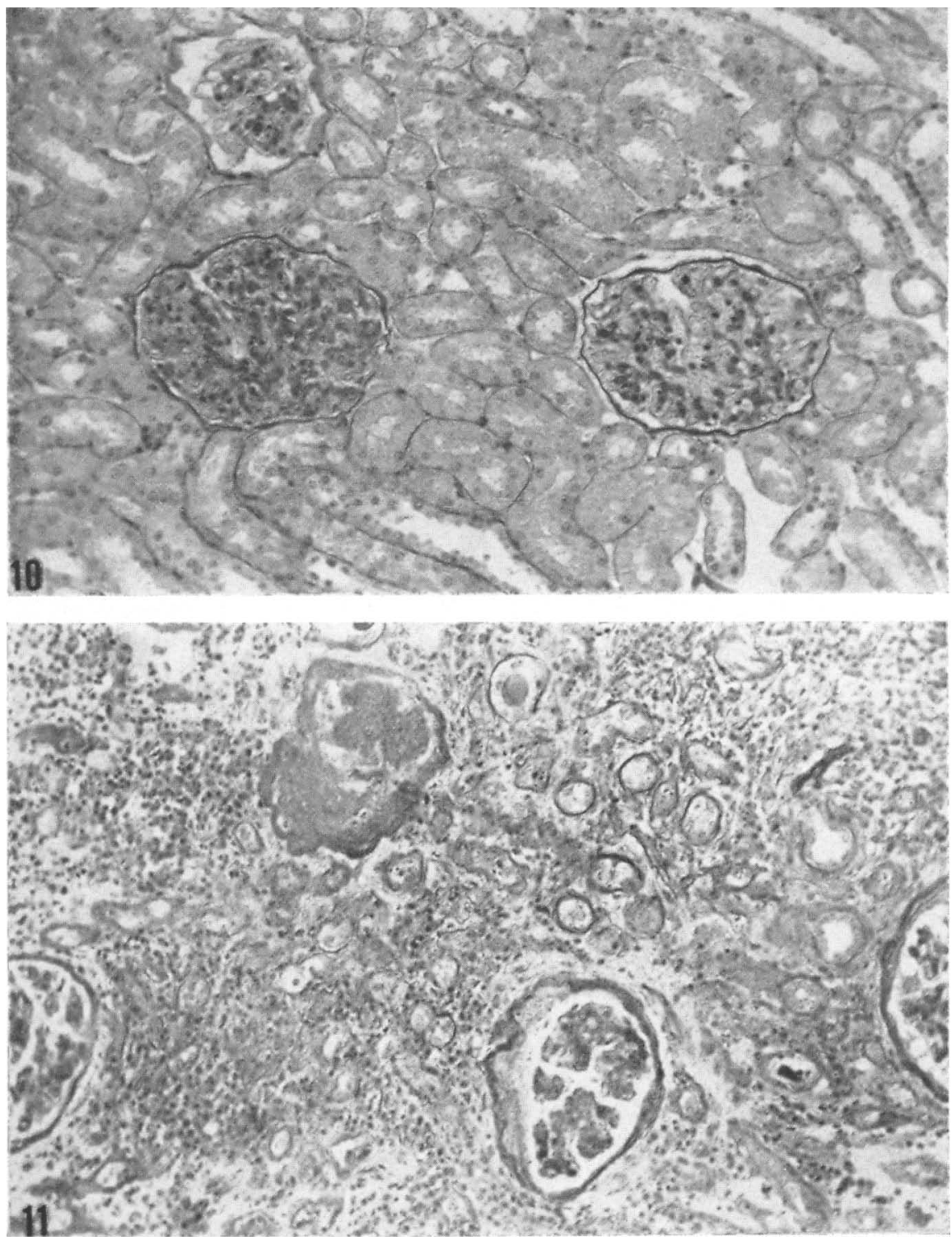

F i g. 1 0. P 3123/62. Moderate membranous glomerulonephritis. More severe changes in the glomerulus to the left. PAS, $150 \times$.

F i g. 11. P 3204/62. Part of the cortex of a kidney with moderate membranous glomerulonephritis. In this area the glomeruli are non-functional and undergoing hyalinization. Adjacent tubules are atrophic and have a greatly thickened PASpositive basement membrane. Abundant plasma cells and fibroblasts in the interstitium. PAS, $150 \times$. 

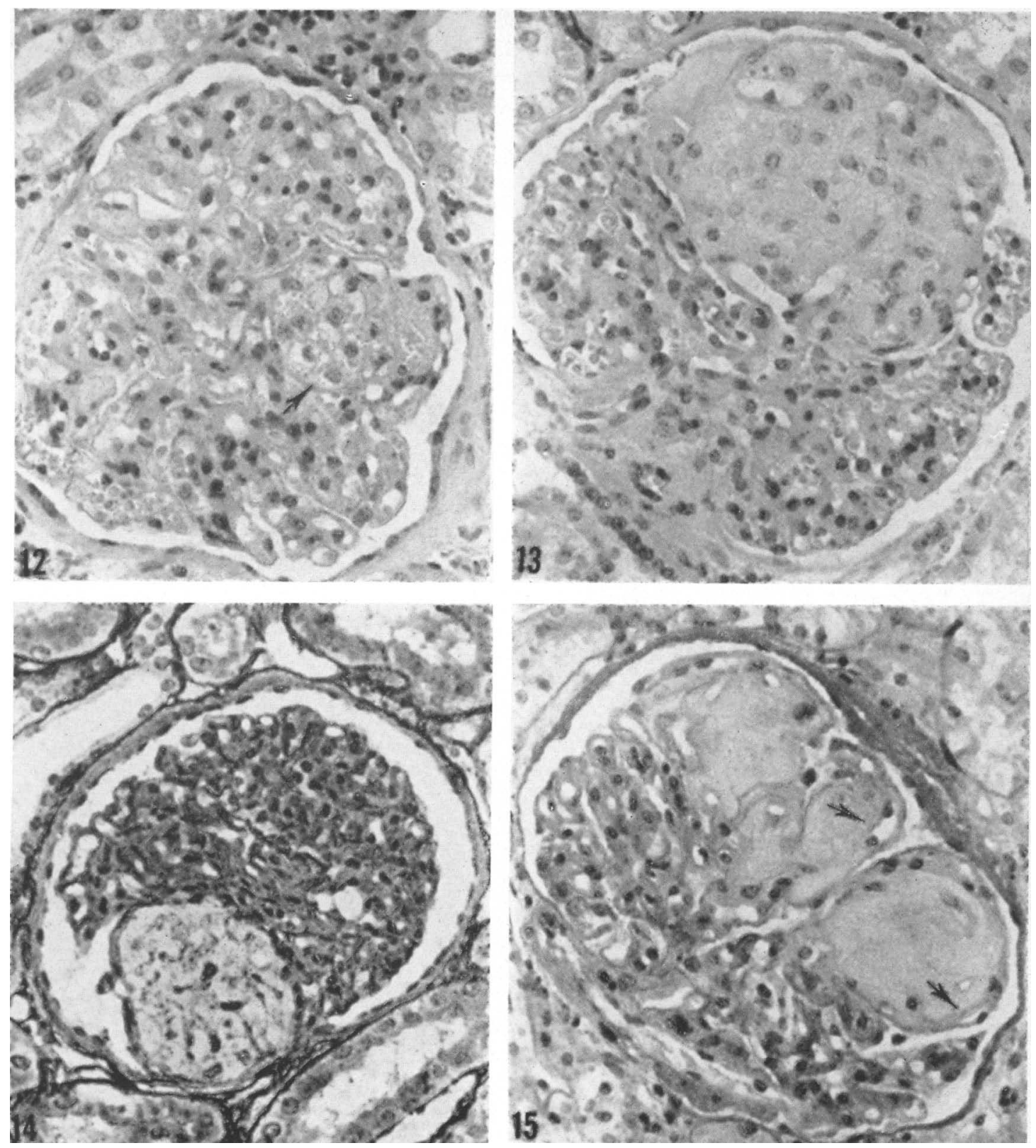

Fig. 12 . $P$ 2866/62. Severe mixed membranous and proliferative glomerulonephritis. The arrow indicates a group of greatly swollen endothelial cells containing abundant PAS-positive granules in their cytoplasm. $\mathrm{H} \& \mathrm{E}, 300 \times$.

Fig. 13 . Same kidney as in Fig. 12. A glomerulus contains a large, hyaline nodule with enclosed cell nuclei. $\mathrm{H} \& \mathrm{E}, 300 \times$.

F i g. 14. Same kidney as in Fig. 12. The hyaline nodule contains cell nuclei and a few silver-positive fibres. Gomori's silver, $300 \times$.

F i g. 15. Same kidney as in Fig. 7. Some lobuli contain hyaline, cell-free, weakly PAS-positive nodules. Residual capillary lumina are indicated by the arrows. PAS, $300 \times$. 


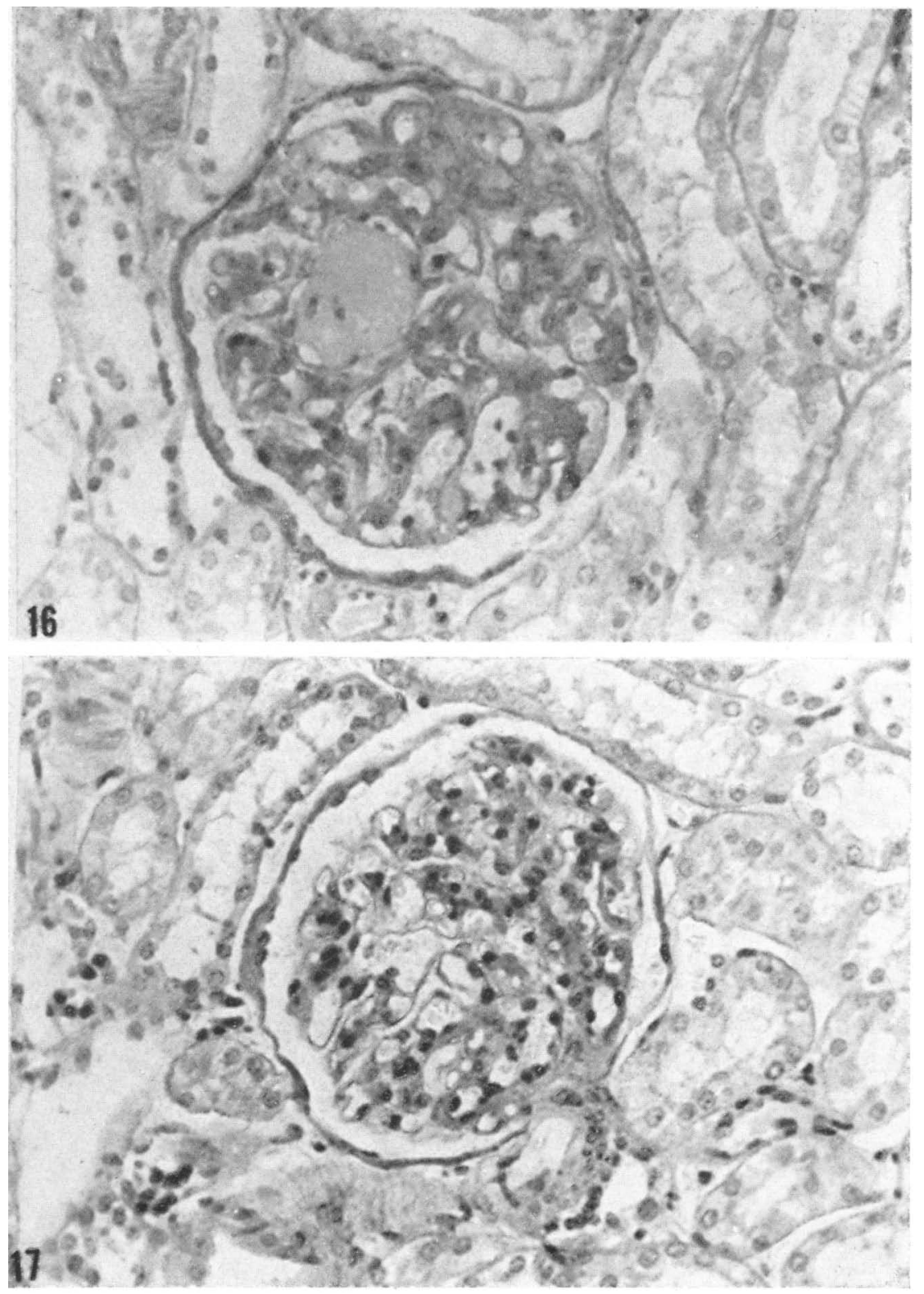

F i g. 16 . P 2866/62. Severe mixed membranous and proliferative glomerulonephritis with hyaline nodules in most glomeruli. Sample taken by biopsy during ovariohysterectomy for pyometra. PAS, $300 \times$.

Fig. 1 7. O 5458/62. Healing after severe mixed membranous and proliferative glomerulonephritis. Slight persistent thickening of the centrilobular portions of the capillary walls with some endothelial proliferation. The hyaline nodules are no longer present. Specimen taken 14 weeks after ovariohysterectomy from the same bitch as in Fig. 16. PAS, $300 \times$. 

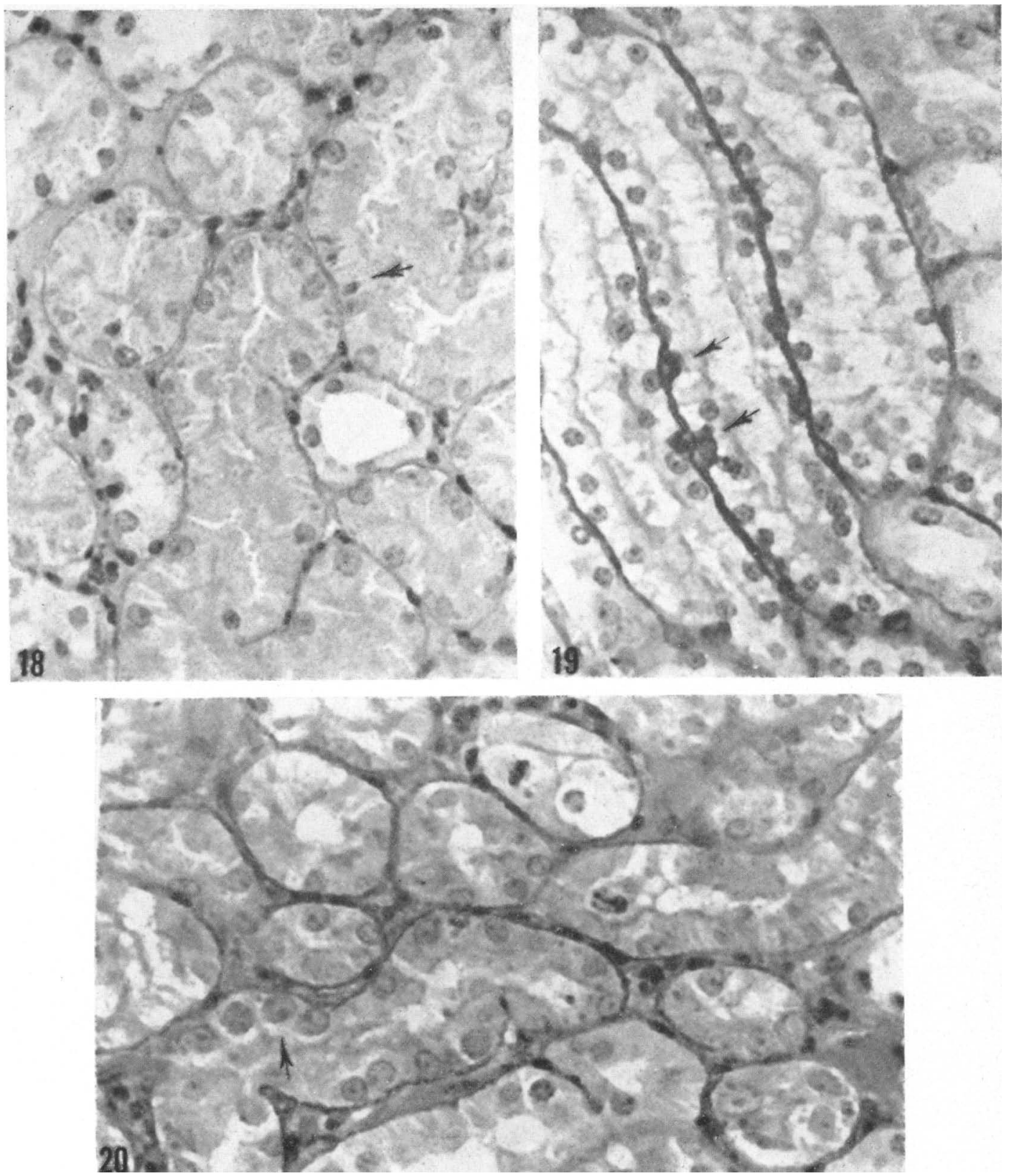

Fi g. 1 8. $P$ 3595/62. Cortical tubules in a kidney with moderate membranous glomerulonephritis. The cytoplasm of the proximal epithelium contains hyaline droplets and yellow-brown granules of lipofuscin pigment (arrow). PAS, $500 \times$.

F i g. 1 9. P 3123/62. Corticomedullary junction in a kidney with moderate membranous glomerulonephritis. The basement membrane in the straight portion of the proximal tubules is greatly thickened and strongly PAS positive. There are a few knobs on the basement membrane which extend up betwen the cells. PAS, $500 \times$.

Fi g. 2 0. P 3205/62. Portion of the cortex from a kidney with moderate mixed membranous and proliferative glomerulonephritis. Focal epithelial proliferation in proximal tubules (arrow). The nuclei are enlarged and have distinct nucleoli. There are also a few mitoses visible. PAS, $500 \times$. 

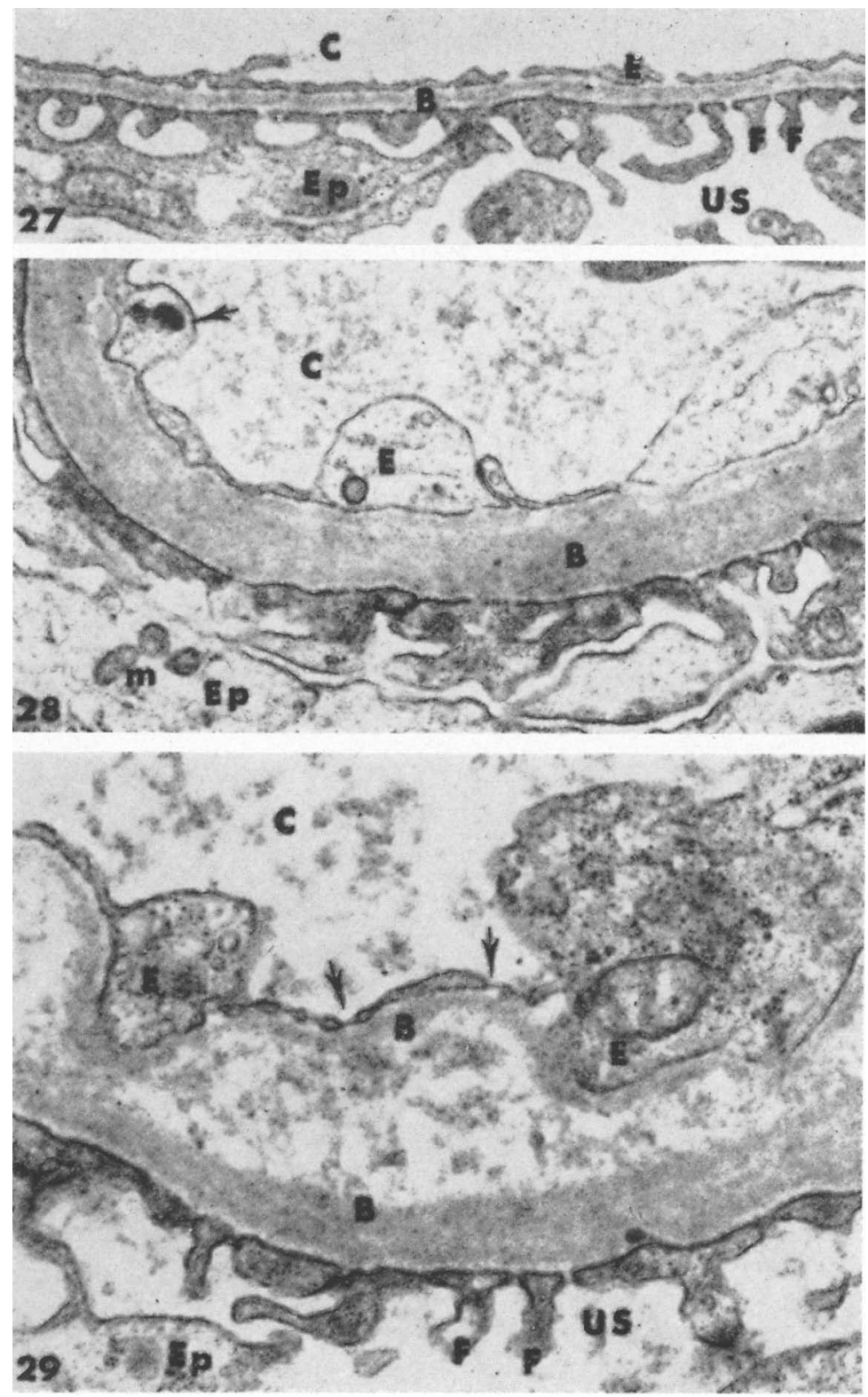

Figures $27-35$ are electron micrographs. The following designations have been used.
C, capillary lumen
B, basement membrane
D, dense deposit
E, endothelium

Ep, epithelium

$\mathbf{F}$, foot processes

G, Golgi apparatus

IS, intercellular space

$\mathrm{L}$, lumen

$\mathrm{m}$, mitchondria

$\mathrm{N}$, nucleus

$\mathrm{P}$, protein absorption droplets

F i g. 2 7. Part of glomerular capillary wall, normal bitch. $15,000 \times$.

F i g. 2 8. Part of glomerular capillary wall from a pyometra bitch. The endothelium is slightly swollen with cytoplasmic inclusions (arrow). The basement membrane is thickened with a suggestion of lamellations and the epithelial foot processes are fused. $16,000 \times$.

F i g. 2 9. Part of glomerular capillary wall from a kidney with severe changes. The internal layers of the basement membrane are light and highly swollen. The attenuated part of the endothelium has normal "pores" (arrows) and the foot processes are largely intact. $25,000 \times$. 


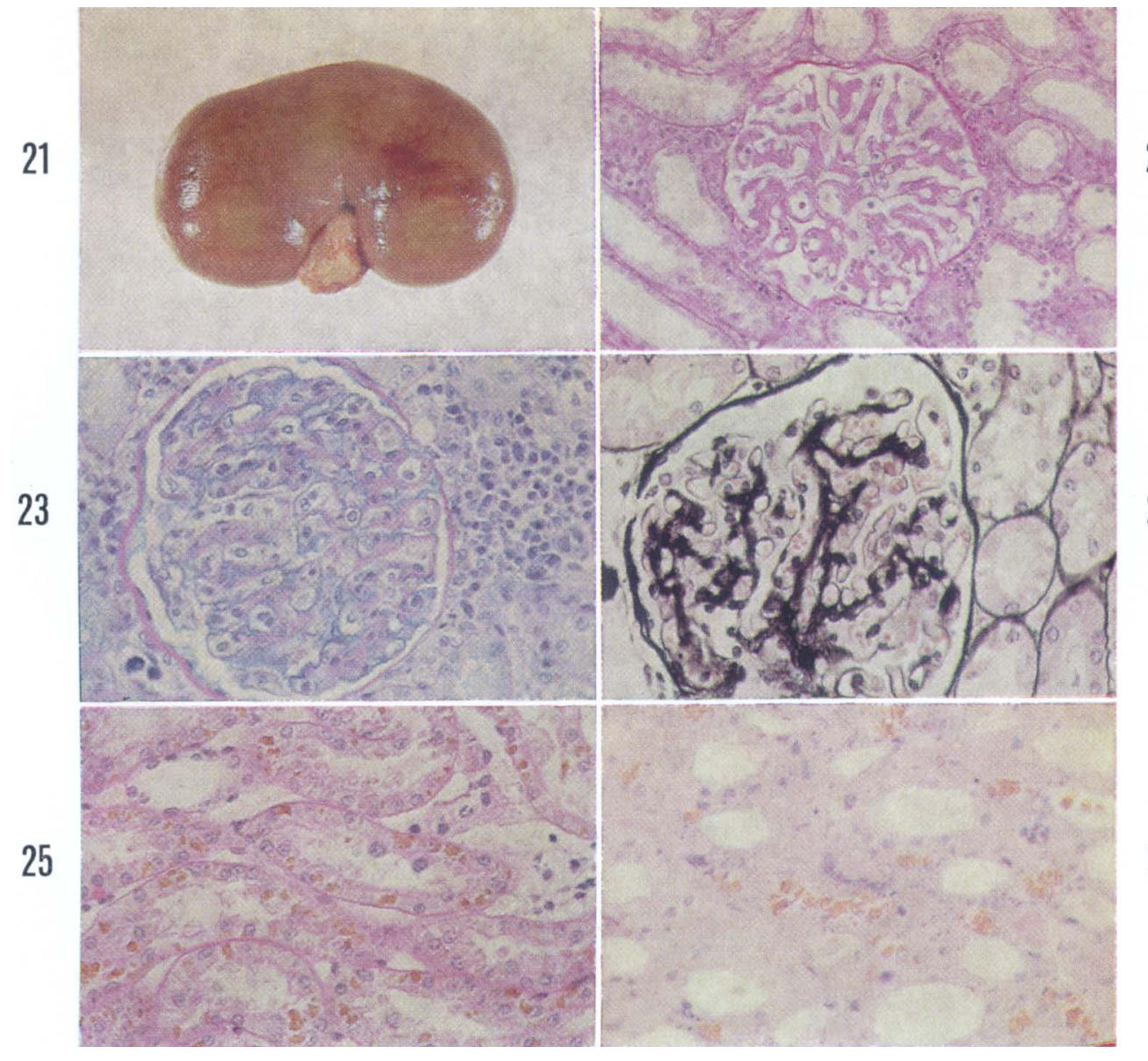

F i g. 2 1. O 1314/63. Kidney from a pyometra bitch; swollen and light in colour. Pitting of the surface.

Fig. 22 . O 1314/63. Severe mixed membranous and proliferative glomerulonephritis. Moderate thickening of the basement membrane and proliferation of the endothelium. PAS.

F i g. 2 3. O 1314/63. Severe mixed membranous and proliferative glomerulonephritis. The basement membrane is clearly thickened. Endothelial proliferation, normal epithelial cells. Ritter-Oleson's method.

F i g. 24. P 2866/62. Moderate membranous glomerulonephritis. Mainly centrilobular thickening of the capillary walls. Focal splitting of the basement membrane. Jones' periodic acid and silver methenamine.

F i g. 2 5. P 4309/62. Cortical tubules from a kidney with moderate membranous glomerulonephritis. The proximal epithelial cells contain abundant yellow-brown lipofuscin granules and weakly PASpositive hyaline droplets. PAS.

Fig. 2 6. P 96/63. Portion of papillary tip from a kidney with severe mixed membranous and proliferative glomerulonephritis. Abundant calcified granules along the connective tissue fibres of the interstitium. $\mathrm{H} \& \mathrm{E}$. 

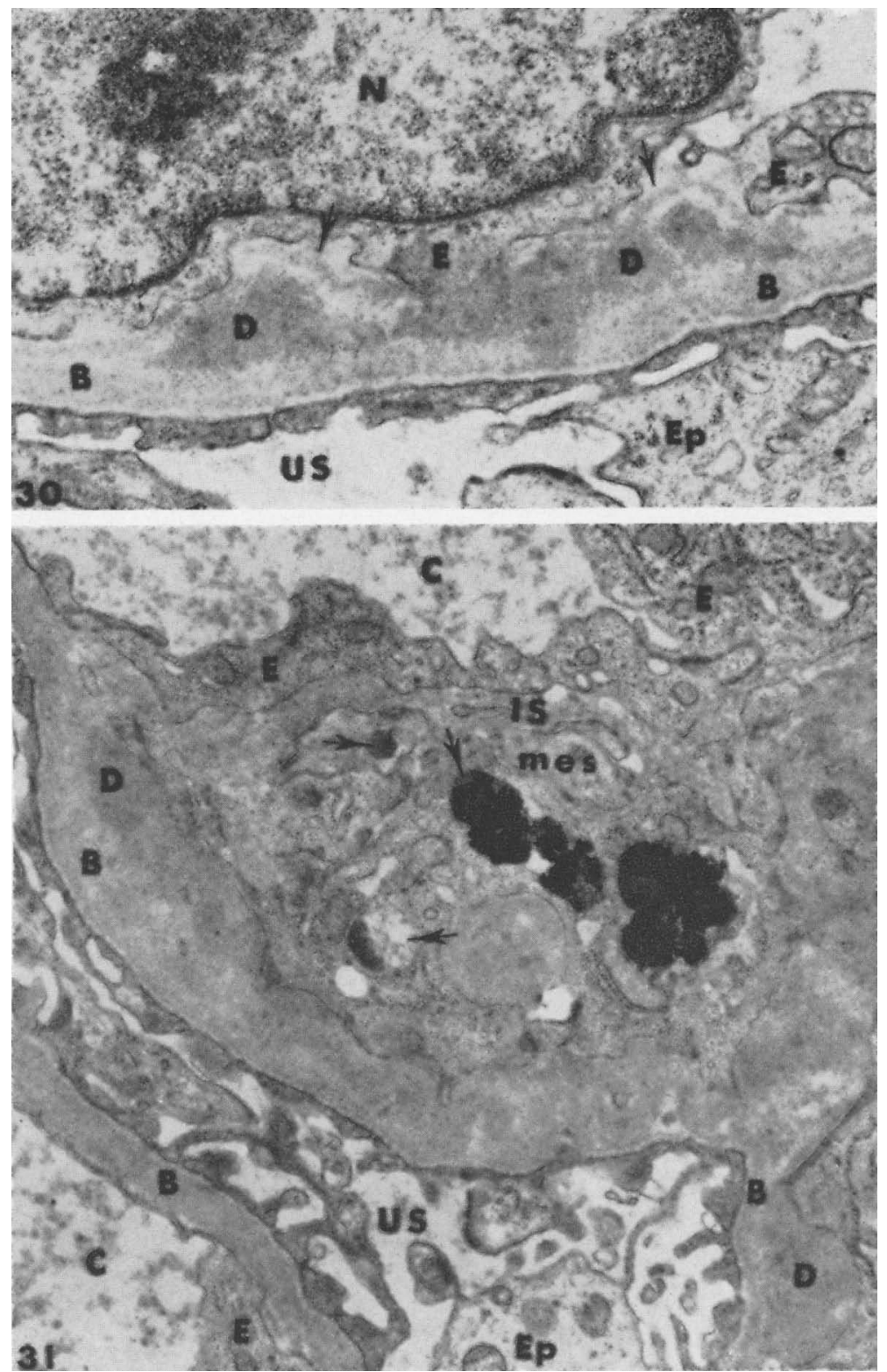

F i g. 3 0. Part of glomerular capillary wall from a kidney with severe changes. Dense deposits appear to be partly separated from the endothelium by narrow strands (arrows) split off from the basement membrane. The foot processes are mostly fused below the area containing the deposits. 19,000 $\times$.

Fig. 31. Part of glomerulus from a kidney with severe changes to show mesangium (mes). A mesangial cell contains different types of inclusions (arrows). Dense deposits are present inside the basement membrane proper. $13,000 \times$. 

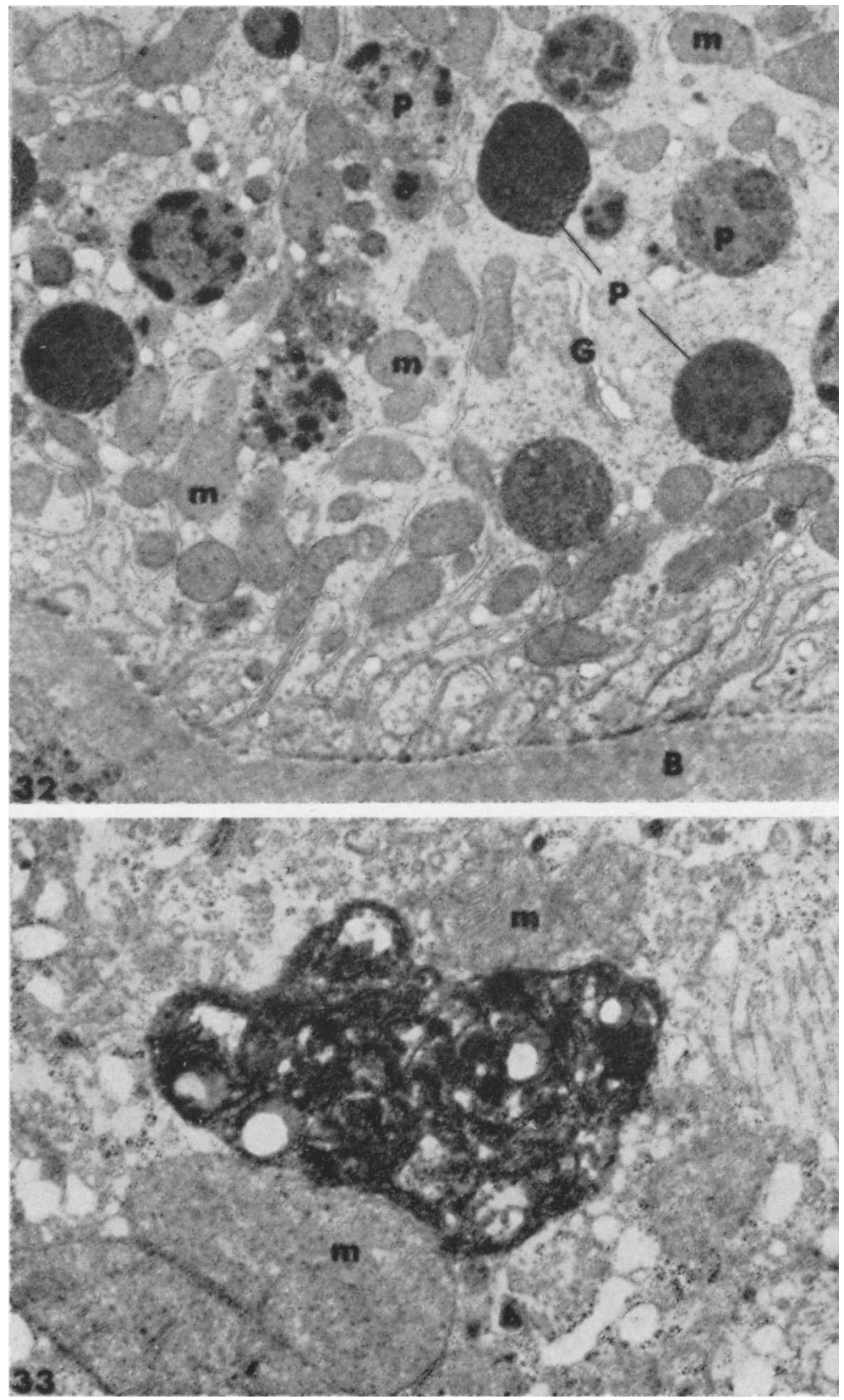

F i g. 3 2. Part of proximal convoluted tubule wall with many protein absorption droplets. $10,000 \times$.

F i g. 3 3. Large, dense inclusion, probably pigment, between two mitochondria in a proximal convoluted tubule cell. 20,000 $\times$. 


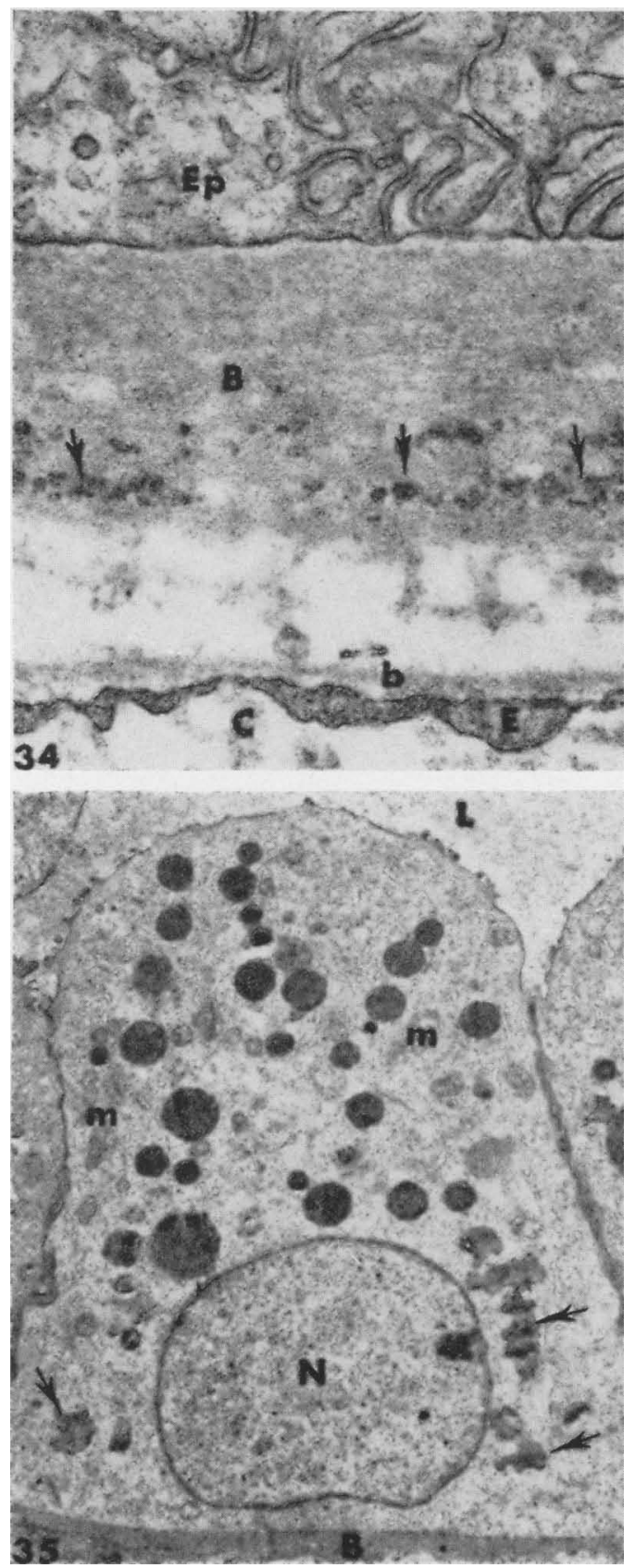

F i g. 3 4. Small cortical area to show the thick basement membrane (B) of a collecting tubule with dense, irregular particles (arrows) within its outer layers. The basement membrane (b) of an adjacent capillary appears normal. 24,000 $\times$.

F i g. 35. A cell in a papillary duct with numerous dense spherical inclusions. The irregular inclusions beside the nucleus probably represent lipid droplets. $5,000 \times$. 